DOI https://doi.org/10.30525/978-9934-26-110-7-83

\title{
THE ROLE OF LITERATURE IN TEACHING AND LEARNING ENGLISH AS A FOREIGN LANGUAGE IN SCHOOLS OF TRANSCARPATHIA (UKRAINE)
}

\author{
Moldovan A. V. \\ 2nd year MA student \\ Department of Philology (English language and literature)
}

Ferenc Rakoczi II Transcarpathian Hungarian College of Higher Education

Beregove, Transcarpathian region, Ukraine

Nagy-Kolozsvari E. A.

Senior Lecturer at the Department of Philology

(English language and literature)

Ferenc Rakoczi II Transcarpathian Hungarian College of Higher Education

Beregove, Transcarpathian region, Ukraine

\section{Introducing the topic}

Several books and studies deal with the importance of literature in the foreign language classroom. Experts who wrote down their implications concerning this topic include Ellis and Brewster [4, p. 55], McKay [9, p. 21], Nunan [10, p. 101] and many others.

Various genres can be applied in the foreign language classroom, but the two most frequent ones are short stories [2, p112], and poetry [3, p76]. These authentic sources play an essential part in creating a learner-friendly and motivating environment in the classroom. Furthermore, literature is useful in developing all the four basic language skills [10, p. 33].

The significance of the present study lies in teaching EFL with the help of literature. More and more educators try to apply literature in the classroom due to the increased awareness of its benefits. In addition, the novelty of the research is based on the excessive amount of the analysed scientific literature about the possibilities of involving authentic materials in language teaching, exploring the main trends among English teachers in this respect.

\subsection{Literature and Language Teaching}

Stories are helpful because they address universal themes beyond the useful level of basic dialogues and daily activities. In addition, they also exercise the children's imagination. Using tales is one of the ways of providing pupils with both comprehensible and exciting input. Stories usually do not offer single meanings but form sets of meanings. Storytelling, therefore, has 
been used to assess a student's ability to think critically. When a teacher uses tales during the lessons, it helps learners think, bring about a form of creativity and imagination, and allow space to transform their experiences into stories. As Cameron highlighted [2, p. 112], literature provides a motivating, meaningful context for language learning since children are naturally drawn to stories. Furthermore, it can contribute to language learning. Stories present the language at its finest and can foster vocabulary development in context. According to Linse [7, p. 90] children's literature should be used in class frequently because it is an exciting medium for language acquisition - it contains predictable, repetitive patterns that reinforce vocabulary and structures and provides relevant themes for young learners.

In The Storytelling Handbook, Ellis and Brewster [4, p. 60] state that tales should be used in the classrooms because they motivate and fun for children, not to mention that they create a deep interest and a desire to continue learning. Furthermore, it can be stated that listening to stories, sharing and retelling them is a shared social experience; therefore, it provokes a shared response.

Referring to Khan [6, p. 140], educators will surely motivate their students if they use the storytelling method and link it to game activities. According to Ahlquist and Lugossy [1, p. 83], most teachers agree that stories make the classroom more colourful and exciting for the learners. It is essential to denote that learning through tales emphasises the relationships between four language skills. Conforming to Halliwell [5, p. 111], reading helps to learn and acquire the English language. Reading at the appropriate level is one of the best and most effective ways for students to get comprehensible input, and by this, children will understand the language more easily.

\subsection{Teachers' and pupils' opinions about the role of literature in teaching and learning English}

Two different questionnaires were designed to investigate the teachers' and learners' opinions concerning using literature while teaching English as a foreign language, focusing on their views and experience in connection with authentic literature, motivation, and creative tasks in the English language classroom. The research was conducted in quantitative form with two online questionnaires. In addition, different types of questionnaire items were used to get a broader understanding of the topic: closed-ended and open-ended questions, Likert scales, and multiple-choice questions.

The first questionnaire was completed by teachers $(\mathrm{N}=55)$ of English as a foreign language. Most of them have maximum 10 years of experience, but some teachers had even more than 20 years of experience teaching English.

The main areas of the research were the following: 
- The importance of using authentic materials in English language teaching;

- The role of literature in making English lessons more exciting and varied;

- The effects and consequences of using literature in the classroom;

- The connection between motivation and language learning;

- The role of teachers and creative tasks in the successful acquisition of a foreign language.

The second questionnaire was filled out by secondary school pupils $(\mathrm{N}=100)$. The main areas of the research included the following topics:

- Pupils' attitude towards learning English;

- Learners' opinion about the use of English poems and stories in the lesson;

- The most important ways of making English lessons more engaging and exciting for the learners;

- Motivation as a key factor in language learning;

- The importance of using creative tasks and reading in English.

\subsection{Main findings}

Authentic materials are a 'must'

Little, Devitt and Singleton [8, p235] believe that authentic materials are incredibly important and contribute greatly to students' familiarity with the English language and its environment. Based on the answers received, most of the educators share this view.

\section{The benefits of using stories in the EFL classroom are inarguable}

According to Cameron [2, p. 201], Ahlquist and Lugossy [1, p. 117], as well as Halliwell [5, p. 108], including stories in lessons makes the subject more interesting, encourages students to pay more attention, and motivates them to learn.

Literature, based on Ellis and Brewster's [4, p79] views, fosters creative thinking. The majority of teachers implied that literature makes the lesson more interesting, as per the survey results, which back up experts' claims.

\section{Students enjoy reading in English}

In the questionnaire, students had the chance to express their agreement or disagreement with some given statements regarding literature, reading and carrying out tasks connected to literary texts. Based on the results, it can be stated that the learners themselves favour tasks that are related to literature.

\subsection{Pedagogical implications}

- In the case of giving out tasks that are connected to essays and writing, teachers often tend to connect the topics of such exercises to literature.

- Since creativity is essential in teaching EFL, it is crucial for teachers to assign learners tasks that are innovative, interesting and allow them to use their imagination. 
- Poems and rhymes help pupils to understand and recall new content more easily.

\section{Conclusion}

The current findings clearly support the relevance of teaching English to young learners through stories. Using stories in teaching is very suitable, inspiring and enjoyable. It was also shown that tales could attract students' attention because they provide challenging topics based on their everyday interests, such as family and friendship. They also give a huge space for fantasy and creativity. By using stories in the classroom, learners can acquire a certain language if the exercises or activities are familiar and enjoyable, thus teaching English with the help of tales guarantees a quality learning environment for the students. The teachers' attitude towards storytelling indicates that they primarily see it as a tool to raise their students' motivation ad to introduce new vocabulary.

\section{References:}

1. Ahlquist, S., Lugossy, R. Stories and Storyline. Hong Kong: Candlin \& Mynard ePublishing at Smashwords, 2015. 296 pp.

2. Cameron, L. Teaching Languages to Young Learners. Cambridge: Cambridge University Press, 2002. 256 pp.

3. Carter, R. \& Long, M. N. Teaching literature. London: Longman, 1991. $200 \mathrm{pp}$

4. Ellis G., Brewster, J. Tell it Again - The Storytelling Handbook for Primary English Language Teachers. London: British Council, 2014. 206 pp.

5. Halliwell, S. Teaching English in the Primary Classroom. London: Longman Group UK Limited, 1993. 161 pp

6. Khan, J. Using Games in teaching English to young learners-Edinburgh: Pearson Longman, 1991. 156 pp.

7. Linse, C.T. Practical English Language Teaching: Young Learners. New York: McGraw-Hill Companies, 2005. 225 pp

8. Little D., Devitt S., Singleton D., Learning foreign languages from

authentic texts: theory and practice. Studies in Second Language Acquisition. Dublin: Authentik, 1989. 14236 - 237 pp

9. McKay, L. Principles and Practices for Teaching English as an International Language United Kingdom: Routledge, 2012. 369 pp.

10. Nunan, D. Language Teaching Methodology: A Textbook for Teachers. New Jersey: Prentice Hall, 1991. 264 pp. 